\title{
Pengambilan Keputusan dalam Menetapkan Strategi Persaingan Usaha Laundry di Dukuh Kupang Surabaya dengan Menggunakan Analisa SWOT
}

\author{
Maria Christina \\ mariakwa.christina@gmail.com \\ Mahasiswi Fakultas Ekonomi dan Bisnis Universitas Narotama
}

\begin{abstract}
ABSTRAK
Tujuan dari studi ini adalah untuk mengetahui fungsi dan tujuan pengambilan keputusan serta merumuskan formulasi strategi kompetitif pada usaha laundry.Penelitian ini merupakan penelitian deskriptif dengan pendekatan kualitatif,dimana dalam penelitian ini tidak menggunakan populasi dan sampel namun hanya menggunakan narasumber untuk mendapatkan informasi yang dibutuhkan.Data yang digunakan adalah data primer dan sekunder.Dari hasil analisis ditemukan beberapa strategi alternatif yang bisa digunakan untuk menang dalam persaingan di tengah maraknya usaha laundry di daerah Dukuh Kupang Surabaya.Pengambilan keputusan yang tepat dalam menetapkan strategi bersaing berpengaruh pada penghasilan usaha laundry.Salah satu strategi yang bisa diterapkan adalah memanfaatkan peluang yang ada dengan cara meminimalkan kelemahan.
\end{abstract}

Kata Kunci ; Pengambilan Keputusan, Analisa SWOT,Strategi Alternatif

\section{PENDAHULUAN}

\subsection{Latar Belakang}

Munculnya persaingan dalam dunia bisnis merupakan hal yang tidak dapat dihindari. Dengan adanya persaingan, maka perusahaan - perusahaan dihadapkan pada berbagai peluang dan ancaman baik yang berasal dari luar maupun dari dalam negeri. Untuk itu setiap perusahaan dituntut untuk selalu mengerti dan memahami apa yang terjadi dipasar dan apa yang menjadi keinginan konsumen. Serta berbagai perubahan yang ada di lingkungan bisnisnya sehingga mampu bersaing dengan perusahaan - perusahaan lainnya. Sudah seharusnya perusahaan berupaya untuk meminimalisasi kelemahan - kelemahannya dan memaksimalkan kekuatan yang dimilikinya. Dengan demikian perusahaan dituntut untuk mengambil keputusan dengan tepat dalam menetapkan strategi yang dapat digunakan untuk menghadapi persaingan.

Dengan adanya tekanan persaingan begitu ketat, sehingga secara langsung atau tidak langsung sangat mempengaruhi kinerja organisasi perusahaan termasuk laundry. Perubahan yang begitu cepat dalam dewasa ini, baik dalam hal teknologi,kebutuhan pelanggan dan siklus produk semakin pendek menyebabkan permasalahan serius bagidunia usaha tak terkecuali usaha kecil dan menengah.

Menurut Simamora (2001:38), keberhasilan perusahaan dalam pemasaran dipengaruhi oleh persaingan pasar. Oleh karena itu, perusahaan perlu mengenali siapa pesaingnya, apa sasaran dan strategi mereka, apa kekuatan dan kelemahan mereka dan bagaimana pola reaksi mereka dalam menghadapi persaingannya. Keunggulan bersaing menurut Porter (1986) adalah kemampuan suatu perusahaan untuk meraih keuntungan ekonomis di atas laba yang mampu diraih oleh pesaing di pasar dalam industri yang sama. Perusahaan yang memiliki keunggulan kompetitif senantiasa memiliki kemampuan dalam memahami perubahan struktur pasar dan mampu memilih strategi pemasaran yang efektif. 
Analisis SWOT (SWOT analysis) yakni mencakup upaya-upaya untuk mengenali kekuatan, kelemahan, peluang, dan ancaman yang menentukan kinerja perusahaan. Informasi eksternal mengenai peluang dan ancaman dapat diperoleh dari banyak sumber, termasuk pelanggan, dokumen pemerintahan, pemasok, kalangan perbankan, rekan diperusahaan lain.

Analisis ini didasarkan pada logika yang dapat memaksimalkan kekuatan (strength) dan peluang (opportunity), namun secara bersamaan dapat meminimalkan kelemahan (weakness) dan ancaman (threats). Proses pengambilan keputusan strategi selalu berkaitan dengan pengembangan misi, tujuan, strategi, dan kebijakan perusahaan. Dengan demikian, perencanaan strategi harus menganalisa faktor-faktor strategi perusahaan (kekuatan, kelemahan, peluang dan ancaman) dalam kondisi yang saat ini.Analisis SWOT membandingkan antara faktor eksternal peluang (opportunity) dan ancaman (threats) dengan faktor internal kekuatan ( strenght) dan kelemahan (weakness).

Faktor ekternal mempengaruhi terbentuknya opportunities and threats ( $\mathrm{O}$ dan $\mathrm{T})$. Dimana faktor ini menyangkut dengan kondisi-kondisi yang terjadi di luar perusahaan yang mempengaruhi dalam pembuatan keputusan perusahaan. Faktor ini mencakup lingkungan industri dan leingkungan bisnis makro, ekonomi, politik, hukum, teknologi, kependudukan, dan sosial budaya.

Faktor internal mempengaruhi terbentuknya strenghts and weaknesses (S dan W). Dimana faktor ini menyangkut dengan kondisi yang terjadi dalam perusahaan, yang mana ini turut mempengaruhi terbentuknya pembuatan keputusan (decision making) perusahaan. Faktor internal ini meliputi semua macam managemen fungsional : pemasaran, keuangan, operasi, sumberdaya manusia, penelitian dan pengembangan, sistem informasi manajemen dan budaya perusahaan (corporate culture).

Perlunya menetapkan strategi usaha juga harus dilakukan oleh usaha laundry,semakin banyaknya usaha laundry yang berdiri di daerah Dukuh Kupang Barat membuat pengusaha laundry harus bisa mengambil keputusan yang tepat dalam menentukan strategi persaingan.Keputusan pembelian akan banyak ditentukan dari strategi yang digunakan.

\subsection{Rumusan Masalah}

1. Bagaimana fungsi dan tujuan pengambilan keputusan dalam menetapkan strategi persaingan pada usaha laundry di Dukuh Kupang Barat Surabaya ?

2. Bagaimana cara pemilik laundry menyusun strategi berdasarkan analisa SWOT ?

3. Bagaimana Proses pengambilan keputusan?

\subsection{Tujuan}

1. Mengetahui fungsi dan tujuan pengambilan keputusan.

2. Mengetahui cara pemilik laundry menyusun strategi berdasarkan analisa SWOT.

3. Mengetahui proses pengambilan keputusan.

\section{TINJAUAN PUSTAKA}

\section{Pengertian Pengambilan Keputusan}

Drommond (1985) berpendapat bahwa pengambilan keputusan merupakan usaha penciptaan kejadian-kejadian dan pembentukan masa depan (peristiwa-peristiwa pada saat pemilihan dan sesudahnya). Pendapat ini menegaskan bahwa pengambilan keputusan merupakan proses pada saat sejumlah langkah yang harus dilakukan dengan pengevaluasian alternatif untuk membuat putusan dari semua alternatif yang ada (Syaruddin:48),dari beberapa definisi dijelaskan di atas, maka disimpulkan bahwa pengambilan keputusan adalah proses 
pemecahan masalah dengan menentukan pilihan dari beberapa alternatif untuk menetapkan suatu tindakan yang ingin dilakukan dalam mencapai tujuan yang diinginkan.

Pengambilan keputusan dengan kreatif dan inovatif. Pengambilan keputusan dengan tidak kreatif mempunyai kecenderungan untuk membuat keputusan secara emosional. Dengan menggunakan kreativitasnya, pengambilan keputusan dapat menemukan alternatif-alternatif untuk memecahkan masalah, kemudian memilih salah satu alternatif yang bermanfaat bagi pencapaian organisasi. Inovasi memungkinkan pengambilan keputusan melaksanakan keputusan dengan baik.

Berdasarkan jenis problemnya dikelompokkan menjadi:

1. Pengambilan keputusan terprogram, yaitu pembuatan keputusan dapat dilakukan dengan menggunakan standar prosedur operasi rutin. Cirinya adalah: Problemnya terstruktur, sederhana dan informasinya tersedia lengkap.Problem dan proses pembuatan keputusannya sudah berulang-ulang terjadi sehingga sudah dapat diperhitungkan dan mempunyai pengalaman menyelesaikannya.

2. Pengambilan keputusan tidak terprogram ialah pengambilan keputusan yang problemnya unik, belum pernah terjadi. Informasi mengenai problem belum tersedia atau sedikit,peraturan, kebijakan, prosedur operasi standar untuk membuat keputusan yang belum ada. (Wirawan, 2014:556).

\section{Pengaruh Pengambilan Keputusan yang Efektif bagi Kemajuan Organisasi}

Sebagai mana yang telah dipaparkan oleh Usman, Husaini (2013 : 312), bahwa kemajuan suatu organisasi dipengaruhi oleh cara pemimpin dalam mengambil keputusan. 


\section{Analisis SWOT}

Salah satu pendekatan yang dapat dipergunakan sebagai instrumen dalam pemilihan strategi dasar adalah melalui analisis SWOT. Analisis SWOT bisa digunakan untuk mengevaluasi kesempatan dan tantangan di lingkungan bisnis maupun lingkungan internal perusahaan (Kuncoro,2005:50). Rangkuti (2009:18) menjelaskan bahwa analisis SWOT adalah identifikasi berbagai faktor secara sistematis untuk merumuskan strategi perusahaan. Analisis ini didasarkan pada logika yang dapat memaksimalkan kekuatan (Strengths) dan peluang (Oportunities), namun secara bersamaan dapat meminimalkan kelemahan (Weakness) dan ancaman (Threats). Proses pengambilan keputusan dengan cara ini selalu dikaitkan dengan pengembangan misi, tujuan, strategi dan kebijakan usaha. Jadi pada prinsipnya analisis SWOT membandingkan antara faktor eksternal (peluang dan ancaman) danfaktor internal (kekuatan dan kelemahan) guna menetapkan formulasi strategi (perencanaan strategi) dalam upaya penyusunan strategi jangka panjang. Menurut David (2006:10) mengatakan bahwa peluang dan ancaman eksternal merujuk pada keadaan ekonomi, sosial, buadaya, demografi, lingkungan, politik, hukum, pemerintah, teknologi, dan kecendrungan persaingan serta peristiwa yang dapat menguntungkan atau merugikan suatu organisasi secara signifikan dimasa depan.

\section{Matriks SWOT}

Untuk memudahkan melaksanakan analisis SWOT diperlukan matriks SWOT, yang dimaksudkan untuk mempermudah merumuskan berbagai strategi yang perlu di jalankan oleh perusahaan. Matrik ini dibuat dengan mengelompokkan masing-masing unsur masalah SWOT ke dalam tabel matriks. Karena matrik SWOT ini adalah alat yang dipakai untuk penyusunan faktor-faktor strategis perusahaan dimana matrik ini nantinya dapat menggambarkan secara jelas bagaimana peluang dan ancaman eksternal yang dihadapi perusahaan dapat disesuaikan dengan kekuatan dan kelemahan yang dimilikinya.

Melakukan analisis SWOT ini Freddy rangkuti (2009:33) menyatakan bisa dibuat suatu matrik dimana masing-masing sel tersebut dapat diisi dengan berpedoman sebagai berikut :

1. Sel Strenghs (S) dibuat 5 sampai 10 kekuatan internal yang dimiliki pada suatu usaha.Yaitu, mencari 5 sampai 10 analisis kekuatan, situasi ataupun kondisi yang merupakan kekuatan dari suatu perusahaan pada saat ini. Yang perlu dilakukan dalam analisis ini adalah setiap perusahaan perlu menilai kekuatan-kekuatan dan kelemahan dibandingkan dengan para pesaingnya.

2. Sel Weaknesses (W) dibuat 5 sampai 10 kelemahan internal yang dimiliki pada suatu usaha. Yaitu, mencari 5 sampai 10 analisis kelemahan, situasi ataupun kondisi yang merupakan kelemahan dari perusahaan pada saat ini. Merupakan cara menganalisis kelemahan di dalam sebuah perusahaan yang menjadi kendala yang serius dalam kemajuan suatu perusahaan.

3. Sel Opportunities (O) dibuat 5 sampai 10 kekuatan eksternal yang dimiliki pada suatu usaha. Yaitu, mencari 5 sampai 10 analisis peluang, suatu kondisi yang 
merupakan peluang diluar suatu perusahaan dan memberikan peluang berkembang bagi perusahaan dimasa depan.

Sel Threats (T) dibuat 5 sampai 10 kelemahan eksternal yang dimiliki pada suatu usaha. Yaitu, mencari 5 sampai 10 analisis ancaman, yang harus dihadapi oleh suatu perusahaan atau organisasi untuk mengadapi berbagai macam faktor lingkungan yang tidak menguntungkan pada suatu perusahaan yang menyebabkan kemunduran.

\section{Definisi Strategi Bersaing}

Hariadi (2005:97-8), strategi bersaing perusahaan merupakan langkah strategi yang terencana maupun tidak terencana untuk dapat memiliki keunggulan bersaing, sehingga dapat menarik perhatian konsumen, memperkuat posisi dalam pasar, dan bertahan terhadap tekanan persaingan. Keunggulan bersaing dalam pasar akan memudahkan perusahaan untuk meraih keuntungan lebih besar daripada pesaing dan memberikan kesempatan hidup lebih lama dalam persaingan. Strategi perusahaan dapat dijalankan secara ofensif atau defensif atau dilakukan bergantian sesuai dengan kondisi dilapangan. Dalam strategi ini, termasuk didalamnya berbagai manuver taktik jangka pendek untuk mengelabuhi lawan, menjegal untuk menahan laju serangan lawan yang semuanya ditujukan untuk memenangkan pertempuran maupun peperangan.

Selanjutnya Hariadi membedakan antara strategi bersaing dan strategi bisnis, strategi bisnis tidak hanya semata berkaitan dengan bagaimana bersaing dengan lawan bisnis ataupun kekuatan-kekuatan dalam pasar, melainkan juga mencakup strategi dalam fungsi-fungsi yang dijalankan perusahaan, dan bagaimana respon manajemen terhadap perubahan kondisi industri yang menyangkut banyak hal (tidak semata-mata persaingan saja). Sementara itu, strategi bersaing hanya fokus pada rencana tindakan manajemen untuk bersaing dengan sukses dan memberikan nilai yang sangat bagus pada konsumen

\section{METODE PENELITIAN}

\section{Jenis Penelitian}

ini merupakan penelitian studi yang lebih bersifat operasional yakni dengan melakukan analisis terhadap lingkungan internal dan eksternal suatu bisnis usaha laundry melalui penerapan analisis SWOT dengan menggunakan pendekatan kuantitatif Matrik SWOT.

\section{Jenis dan Sumber Data}

Untuk membantu penulis dalam penelitian ini, penulis menggunakan jenis sumber data sebagai berikut:

a. Data Primer, merupakan data yang diperoleh secara langsung dari objek penelitian melalui wawancara langsung kepada pengelola (supervisor), 
pramuniaga beberapa laundry di daerah Dukuh Kupang Barat yang diberikan beberapa pertanyaan-pertanyaan yang terkait seputar faktor lingkungan bisnis apa yang dimiliki oleh bisnis usaha tersebut.

b. Data sekunder, merupakan data-data yang diperoleh dari sumber lain yang mempunyai keterkaitan dengan penelitian ini. Data sekunder dari penelitian ini adalah hasil penelitian terdahulu, literatur, dan data-data dari objek penelitian yang diperlukan dalam penyusunan dalam penyusunan penelitian ini

\section{Teknik Pengumpulan Data}

Teknik pengumpulan data dalam penelitian ini adalah: Wawancara

Dimana peneliti mengadakan tanya jawab langusng dengan pengelola (supervisor), pramuniaga, dan konsumen beberapa usaha laundry di daerah Dukuh Kupang Barat untuk memperoleh keterangan-keterangan yang berhubungan dengan masalah penelitian.

\section{Analisis Data}

Analisis data kualitatif adalah proses analisis kualitatif yang mendasarkan pada adanya hubungan semantis antar variabel yang sedang diteliti. Tujuan analisis data kualitatif yaitu agar peneliti mendapatkan makna hubungan variabelvariabel sehingga dapat digunakan untuk menjawab masalah yang dirumuskan dalam penelitian. Hubungan antar semantis sangat penting karena dalam analisis kualitatif, peneliti tidak menggunakan angka-angka seperti analisis kuantitatif. Prinsip pokok teknik analisis data kualitatif ialah mengolah dan menganalisis data-data yang terkumpul menjadi data yang sistematik, teratur, terstruktur dan mempunyai makna.

Teknik analisis data yang digunakan dalam penelitian ini adalah :

a. Metode Analisis Deskriptif

Metode Analisis Deskriptif merupakan cara merumuskan data yang ada sehingga memberikan gambaran yang jelas mengenai masalah yang ada serta daya saing usaha laundry yang dilihat dari analisis SWOT.

b. Matriks Analisis SWOT

Analisis ini dilakukan dengan menggunakan matrik SWOT (Freddy Rangkuti, 2009:31) merupakan alat yang digunakan untuk menggambarkan secara jelas bagaimana peluang dan ancaman eksternal yang dihadapi perusahaan dapat disesuaikan dengan kekuatan dan kelemahan yang dimilikinya. Matriks ini menghasilkan empat set kemungkinan alternatif strategi.

\section{PEMBAHASAN}

\section{SWOT (Strengh, Weakness, Opportunity, Threats) pada Usaha Laundry •}

Pada bagian ini menggambarkan setiap kekuatan, kelemahan, peluang, serta ancaman dari bisnis usaha ini dalam melaksanakan aktivitasnya. Terdapat suatu kondisi lingkungan yang dihadapi perusahaan yang berasal dari dalam lingkungan 
bisnis itu sendiri (kekuatan dan kelemahan) maupun dari lingkungan luar bisnis (peluang dan ancaman).

Dalam penelitian ini wawancara dilakukan kepada key informan yang mengetahui permasalahan secara mendalam, key informan dalam penelitian ini ialah pemilik usaha Laundry.Lokasi penelitian adalah beberapa usaha laundry di daerah Dukuh Kupang Barat Surabaya yang membuka jam kerja mulai jam/pukul : 08.00 - 21.00 WIB.Tarif laundry beraneka ragam dari harga 6000/kg-8000/kg. Rata-rata menggunakan tiga mesin cuci, satu unit pengering pakaian, 8 unit setrika dan 2 unit setrika uap yang semuanya baru. Tempat atau lokasi sangat strategis, berada di ruang lingkup perumahan Dukuh Kupang Barat yang banyak ditemukan kos mahasiswa Universitas Wijaya Kusuma Surabaya

\section{Analisis SWOT :}

1. Strength (S) memiliki kekuatan seperti Usaha tepat berada di pinggir jalan, kualitas pelayanan yang diutamakan, dan usaha berada di dekat Universitas

2. Weakness (W) memiliki kelemahan seperti kurangnya ketelitian karyawan dalam bekerja, kurangnya lahan jemuran, dana operasional, belum melakukan inovasi terhadap usaha dan SDM yang terbatas

3. Opportunity $(\mathrm{O})$ memiliki peluang usaha seperti lokasi usaha yang strategis, jumlah konsumen yang semakin meningkat, dan pangsa pasar yang masih terbuka 4. Threats (T) memiliki ancaman usaha seperti banyaknya muncul laundry rumahan, dan munculnya perusahaan pesaing 


\section{Alternatif Strategi}

Manajemen strategi adalah seni dan ilmu penyusunan, penerapan, dan pengevaluasian keputusan-keputusan. Manajemen strategi berfokus pada proses penetapan tujuan perusahaan, pengembangan kebijakan dan perencanaan mencapai sasaran, serta mengalokasikan sumber daya untuk menerapkan kebijakan dan merencanakan pencapaian tujuan perusahaan. Defenisi manajemen strategi dibagi menjadi dua bagian, yaitu :

a. Alternatif strategi adalah suatu seni dan ilmu dari perumusan (formulating), Penerapan (implementing), evaluasi (evaluating), dari keputusan-keputusan strategis antar fungsi yang memungkinkan organisasi dapat mencapai tujuannya di masa yang akan datang.

b. Alternatif strategi adalah pola-pola berbagai tujuan serta kebijaksanaan dasar rencana-rencana untuk mencapai tujuan tersebut, dirumuskan sedemikian rupa sehingga jelas usaha apa yang sedang dan akan dilaksanakan oleh perusahaan, demikian juga sifat perusahaan baik sekarang maupun dimasa yang akan datang.

Penulis menarik kesimpulan dari kedua definisi alternatif strategi diatas bahwa alternatif strategi adalah suatu berbagai macam cara yang direncanakan untuk bertujuan mencapai suatu tujuan tertentu agar tercapai sesuai dengan tujuan.

Tujuan utama perencanaan strategi adalah agar perusahaan dapat mengantisipasi perubahan lingkungan eksternal. Dalam hal ini dapat dibedakan secara jelas, fungsi manajemen, konsumen, distributor, dan pesaing. Jadi perencanaan strategis penting untuk memperoleh keunggulan bersaing dan memiliki produk yang sesuai dengan keinginan konsumen dengan dukungan yang optimal dari sumber daya yang ada.

\section{KESIMPULAN}

Dari berbagai uraian di atas maka dapat disimpulkan bahwa :

Pemgambilan keputusan merupakan proses memilih sejumlah alternatif penting bagi pemimpin. Pengambilan keputusan juga bisa dipandang sebagai proses memilih dari berbagai alternatif untuk memecahkan masalah dalam rangka pencapaian tujuan sebuah perusahaan.Pengambilan keputusan yang efektif perlu dilakukan oleh seorang pemimpin dalam sebuah perusahaan. Pengambilan keputusan yang efektif dapat berpengaruh terhadap peningkatan kualitas perusahaan yang dalam implementasinya bisa melalui variabel perantara yaitu meningkatnya kinerja, semangat, kreativitas dari karyawan-karyawan yang dipimpinnya.

Berdasarkan hasil analisis yang telah dilakukan pada beberapa usaha laundry di daerah Dukuh Kupang Barat Surabaya dapat disimpulkan bahwa strategi yang efektif digunakan yaitu menggunakan strategi untuk dapat bersaing yakni, strategi SO (Strenghs- Opportunity) dimana menggunakan semua kekuatan yang dimiliki untuk memanfaatkan peluang yang ada 


\section{DAFTAR PUSTAKA}

Alimudin, A. (2015). Strategi pengembangan minat wirausaha melalui proses pembelajaran. E-Jurnal Manajemen Kinerja, 1(1).

Alimudin, A., \& Sukoco, A. (2017). The Leadership Style Model That Builds Work Behavior Through Organizational Culture. JURNAL LENTERA: Kajian Keagamaan, Keilmuan Dan Teknologi, 3(2), 362-375.

Alimudin, A., \& Sasono, A. D. (2015). Peningkatan daya saing produk konveksi usaha kecil berbasis iptek di desa tri tunggal kecamatan babat lamongan. In Seminar Nasional Teknologi Terapan SV UGM.

Alimudin, A., \& Yoga, H. (2015). STRATEGI MENINGKATKAN LOYALITAS PELANGGAN PADA USAHA KECIL PRODUK MAKANAN RINGAN DI SURABAYA. Sustainable Competitive Advantage (SCA), 5(1).

Anzizhan, Syafaruddin. Sistem pengambilan keputusan pendidikan.Ebook.

David, Fred R,2006.Manajemen Strategis. Jakarta: Salemba Empat

Didi Wahyu Sudirman. 2003. Pengambilan Keputusan sebagai Langkah Strategis Tugas Manajer. journal.uny.ac.id, 3(2): 93-101.

Rangkuti Freddy. 1997. Analisis SWOT Teknik Membedah Kasus Bisnis.

Sugiyono, 2011, Metode Penelitian Kuantitatif Kualitatif dan R \& D, Alfabeta,Bandung. 